\title{
The Relationship Between Family-Centeredness of Service Delivery and Parental Satisfaction with Home and Community Participation of Their Children with Cerebral Palsy
}

\author{
Milena D. Milićevića , Goran M. Nedovićb \\ ${ }^{a}$ Institute of Criminological and Sociological Research, Belgrade, Serbia \\ ${ }^{b}$ University of Belgrade - Faculty of Special Education and Rehabilitation, Belgrade, Serbia
}

This descriptive and exploratory study aimed to examine the relationship between familycenteredness of service delivery and home and community participation of children with cerebral palsy. It was hypothesized that there would be a significant association between family-centeredness of service delivery and parental satisfaction with home and community participation in the group of school-aged children with cerebral palsy. A convenience sample included 110 children with cerebral palsy, aged 7-18 years (55\% males; $\mathrm{M}$ age $=12.7$ years, SD =3.41). The Measure of Processes of Care (MPOC-20) was used to assess the extent to which parents of children with cerebral palsy perceived health and rehabilitation services they had been receiving as being family-centred. Overall parental satisfaction with their child's home and community participation was evaluated by The Participation and Environment Measure for Children and Youth (PEM-CY). Analyses were performed using Spearman's rank correlation test. Only two out of 10 tested correlations reached the level of statistical significance, both in home environment. Parents who had higher overall satisfaction with their child's current home and community participation perceived certain aspects of health and rehabilitation services as being family-centred to a greater extent (general and specific information). The fulfilment of parents' needs by presenting them general and child-related information could have a positive effect on their satisfaction with their child's home participation. The findings suggest insufficient representation of the concept of participation and family-centred work principles in service planning and the evaluation of outcomes of the applied programs.

Keywords: participation, children with cerebral palsy, family-centred service, family support

Correspondence: Milena Milićević, milena.milicevic@iksi.ac.rs

Note. This paper is a result of the project "Crime in Serbia: Phenomenology, Risks and the Possibilities of Social Intervention" (No. 47011), financed by the Ministry of Education, Science and Technological Development of the Republic of Serbia. 


\section{Introduction}

Participation is defined as a person's "involvement in life situations" (World Health Organization, 2001). For children with disabilities, participation in activities at home, school and the community is an important rehabilitation goal (Coster et al., 2012). Moreover, optimal participation is set as a fundamental purpose of work in health and education with children, adolescents and adults with impairments, and their families as well (Imms, 2020). This attitude is justified given that a person's involvement in meaningful occupations or activities has an ultimate contribution to their physical, mental, and social wellbeing (Law, 2002).

Family-centeredness is widely accepted and represents a set of ideas, philosophies, attitudes, and approaches in providing services to children and their families (Rosenbaum et al., 1998). Common to many definitions is "the recognition that the family is the constant in a child's life" (Rosenbaum et al., 1998 , p. 5). In this conceptual model, the focus of services is on the family, and service delivery is based on partnership between parents and professionals. Moreover, the partnership between parents and professionals, supportive and respectful treatment, and information exchange are the three elements that are considered crucial (Rosenbaum et al., 1998). In this model, the family is the unit of attention, the focus of assessment, planning and intervention, while support is provided through cooperation and following the individual needs, strengths and wishes of each family separately (Allen \& Petr, 1996). Equality, mutuality and teamwork describe the nature of that partnership between family members with professionals (Allen \& Petr, 1996, p. 64). There are three basic premises of family-centred service (Rosenbaum et al., 1998). According to the first one, parents are the ones who know the child best and want what is best for their child. The second premise is the basis of individualization of services because it highlights the diversity and uniqueness of each family. Finally, the third assumption speaks concerns the influence of the child's primary environment on his development. The family needs component is, by its nature, variable and anticipates the possibility of change; it is a holistic approach to family circumstances, interests and resources (Allen \& Petr, 1996).

One of the most common physically disabling conditions in childhood is cerebral palsy (Rosenbaum, 2003, 2009; Rosenbaum et al., 2007). As previously found, children with cerebral palsy face greater restriction to participation in both home and community-based activities, including leisure activities (EngelYeger et al., 2009; Imms, 2008; Imms et al., 2008; Majnemer et al., 2008; Milićević, 2019; Milićević et al., 2017; Shikako-Thomas et al., 2008).

When it comes to children with cerebral palsy, a foundational approach in service delivery is family-centred caregiving, often associated with a multitude of positive outcomes for both children and their parents and families (King \& Chiarello, 2014). Moreover, decisions about health care, education, 
rehabilitation, professional training and future employment of children with disabilities, including children with cerebral palsy, are usually made according to parents' reports. Therefore, families are encouraged to be an active part of this process (Darrah et al., 2002; Davis et al., 2012). Providing information or referring to support services or counselling is essential, but not sufficient. Healthcare practitioners and rehabilitation therapists must take a more active part beyond the plain, everyday provision of information (Arakelyan et al., 2019).

Previous studies have emphasized the effectiveness and multiple benefits that a family-centred approach have on service delivery (King \& Chiarello, 2014; King et al., 1999; King, Teplicky, et al., 2004; Rosenbaum et al., 1998). There are clear indications that service or support should be provided in a way that focuses on the family. Issues related to the availability of social support, family functioning and child problem behaviour should be included, as well (King et al., 1999). Numerous studies have examined various aspects of familycentred care and their association with child, parent/family and service system outcomes (King \& Chiarello, 2014; King et al., 1999; King, Teplicky, et al., 2004). Although sociodemographic factors were associated with parental perceptions of family-centeredness of service delivery, child-related factors were not (Shevell et al., 2019). Designing interventions that target the family and implementing strategies that improve families' access to information, counselling, and community support can improve children's participation (Arakelyan et al., 2019). However, to our knowledge, little is known about how parent's perceptions of their child's participation and family-centeredness of service delivery are related.

\section{Research aim}

This research aimed to examine the relationship between familycenteredness of service delivery and home and community participation of children with cerebral palsy. Family-centeredness of service delivery is expressed through the extent to which parents perceived the health and rehabilitation services they had been receiving as being family-centred. Participation of children with cerebral palsy is expressed through overall parental satisfaction with their child's home and community participation.

\section{Research hypothesis}

The following research hypothesis was addressed: there would be a significant association between family-centeredness of service delivery and parental satisfaction with home and community participation in the group of children with cerebral palsy. 


\section{Method}

\section{Procedure}

Using the convenience sampling method, parents of children with cerebral palsy were contacted through special schools, rehabilitation centres, hospitals, and several associations of persons with cerebral palsy or associations of persons with disabilities. A total of 65 different institutions and organizations from 48 municipalities in Serbia were contacted, and 35 (54\% response rate) permitted us to access their registers and select potential participants. The inclusion criteria were the following: children of both genders, aged 7-18 years, residing with their families on the territory of the Republic of Serbia, diagnosed with cerebral palsy according to the $10^{\text {th }}$ revision of the International Statistical Classification of Diseases and Related Health Problems (ICD-10; World Health Organization, 2004). The Professional Boards of The University of Belgrade approved the study (No. 61206-2385/2-14). Participation was voluntary. Parents were all informed of their right to refuse to participate or to withdraw their consent to participate at any time without reprisal. A letter, with information about the study, accompanied the questionnaires. Signed informed consents were returned with the completed questionnaires. The data had been gathered from June 2014 to April 2015.

The preliminary sample included 209 potential participants. The final sample was formed under the additional criterion, which was correctly filled in questionnaires, following the authors' arbitrary rule on missing and not valid responses (King, King, et al. 2004). A total of 117 (56\% response rate) parents accepted to participate in this study. However, after the database was created, seven questionnaires were excluded due to missing or not valid responses, giving the final response rate of $53 \%$. As presented in Table 1 , the majority of respondents were mothers ( $75 \%$ ), aged $35-44$ years $(57 \%)$, with high levels of education ( $85 \%$ graduated from high school or college/university). Most families resided in urban areas (57\%) with an average family income of 165-410 euros per month (47\%).

\section{Sample}

Our sample consisted of 110 children with cerebral palsy, 61 (55\%) males and 49 $(45 \%)$ females (Table 1). The mean age of children was 12.7 years $(S D=3.41)$. The most common was a spastic type of cerebral palsy (70\%), accompanied by cognitive (67\%) and visual impairments (34\%), as well as epilepsy (25\%). Forty-four (40\%) children with cerebral palsy were non-ambulatory (GMFCS IV and V). 


\section{Table 1}

Child and respondent characteristics

\begin{tabular}{|c|c|c|}
\hline Variables & & $n(\%)$ \\
\hline \multirow{2}{*}{ Child gender } & Male & $61(55.4)$ \\
\hline & Female & $49(44.6)$ \\
\hline \multirow{3}{*}{$\begin{array}{l}\text { Child age } \\
\text { (years) }\end{array}$} & $7-12$ & $48(43.6)$ \\
\hline & $13-18$ & $62(56.4)$ \\
\hline & I / II & $15(13.6) / 29(26.4)$ \\
\hline \multirow[t]{3}{*}{ GMFCS } & III & $22(20.0)$ \\
\hline & $\mathrm{IV} / \mathrm{V}$ & $29(26.4) / 15(13.6)$ \\
\hline & $\begin{array}{l}\text { Spastic quadriplegia / diplegia / } \\
\text { hemiplegia }\end{array}$ & $37(33.6) / 25(22.7) / 15(13.6)$ \\
\hline \multirow{3}{*}{$\begin{array}{l}\text { Type of } \\
\text { cerebral palsy }\end{array}$} & Dyskinetic / Athetoid & $12(10.9)$ \\
\hline & Ataxic & $11(10.0)$ \\
\hline & Mixed & $10(9.1)$ \\
\hline \multirow{4}{*}{$\begin{array}{l}\text { Comorbidities } \\
\text { and associated } \\
\text { conditions }\end{array}$} & $\begin{array}{l}\text { Sensory impairments (visual / } \\
\text { hearing / combined) }\end{array}$ & 37 (33.6) / 4 (3.6) / 9 (8.2) \\
\hline & Epilepsy & $28(25.5)$ \\
\hline & Cognitive impairment & $74(67.3)$ \\
\hline & Health problems & $23(20.9)$ \\
\hline \multirow{3}{*}{$\begin{array}{l}\text { Respondent } \\
\text { relation to child }\end{array}$} & Mother & $83(75.4)$ \\
\hline & Father & $18(16.4)$ \\
\hline & Guardian & $9(8.2)$ \\
\hline \multirow{3}{*}{$\begin{array}{l}\text { Respondent age } \\
\text { (years) }\end{array}$} & $25-34$ & $16(14.5)$ \\
\hline & $35-44$ & $63(57.3)$ \\
\hline & $44+$ & $31(28.2)$ \\
\hline \multirow{4}{*}{$\begin{array}{l}\text { Respondent } \\
\text { education }\end{array}$} & Primary school & $9(8.2)$ \\
\hline & High school & $69(62.7)$ \\
\hline & Graduated college / university & $24(21.8)$ \\
\hline & Missing data & $8(7.3)$ \\
\hline \multirow{4}{*}{$\begin{array}{l}\text { Family income } \\
\text { per month } \\
(E U R)^{a}\end{array}$} & $<165$ & $26(23.6)$ \\
\hline & $165-410$ & $52(47.3)$ \\
\hline & $410-820$ & $20(18.2)$ \\
\hline & $>820$ & $12(10.9)$ \\
\hline \multirow{3}{*}{$\begin{array}{l}\text { Type of } \\
\text { community }\end{array}$} & Urban & $63(57.3)$ \\
\hline & Suburban / Small town & $21(19.1)$ \\
\hline & Rural & $26(23.6)$ \\
\hline
\end{tabular}

Note. GMFCS - Gross Motor Function Classification System.

${ }^{\text {a }}$ Converted from RSD 2015-12-11. 


\section{Measures}

The Measure of Processes of Care (MPOC-56) is a generic, self-administered, and parent-completed questionnaire that can be used for clinical and research purposes (King et al., 1995, 1996). Later, MPOC-56 was shortened and improved, thus creating the MPOC-20 (King, King, et al., 2004). In this study, a Serbian translation of MPOC20 (Taboroši, 2015) was used to measure the extent to which parents of children with cerebral palsy perceived health and rehabilitation services they had been receiving as being family-centred. Detailed information about the psychometric characteristics of the Serbian version of this scale is described elsewhere (Taboroši, 2015).

The questionnaire MPOC-20 comprises 20 items covering five factoranalytically constructed scales: Enabling and partnership (three items); Providing general information (five items); Providing specific information about the child (three items); Co-ordinated and comprehensive care (four items); Respectful and supportive care (five items). All items are given in the form of a question referring to the situations experienced by parents during the past year. Each question begins the same: "To what extent do the people who work with your child..." followed by an item, for example, "fully explain treatment choices to you?" or "provide you with written information about your child's progress?" Answers are presented on a seven-point scale, ranging from "never" (1), or "not applicable" (0) to "to a great extent" (7). Mean scores were calculated for each scale separately. Higher scores indicate that parents have perceived the service delivery as being family-centred to a greater extent. On average, it takes five to $10 \mathrm{~min}$ to complete MPOC-20 (King, King, et al., 2004). Internal consistency of MPOC-20 in Serbian was .96 (Taboroši, 2015). In this study, internal consistency ranged from .77 in Enabling and partnership to .91 in Providing general information, indicating good to excellent reliability of MPOC-20.

The Participation and Environment Measure for Children and Youth (PEMCY; Coster, Law, \& Bedell, 2010) in Serbian was used to measure the participation of children with cerebral palsy from the perspectives of their parents. PEM-CY combines the assessment of children's participation and the environment across three settings: home, school and community, taking between 15 and 20 minutes to complete. For this study, the home and community sections, each containing 10 activity types, were selected. For both settings, the dichotomous (Yes/No) question was used ("Would you like your child's participation to change in this type of activity?"). To calculate the Change desired score, the number of "yes" responses was divided by the total number of items rated and then multiplied by 100 (range $=0-100 \%$ ). Higher scores represent a greater number of activities that parents have desired change in their child's participation, thus indicating lower overall parental satisfaction with the child's current home and community participation. Detailed information about the conceptual basis, development, and psychometric properties of the PEM-CY have been described elsewhere (Coster et al., 2011; King, King, et al., 2004). Internal consistency of PEMCY ranged from .77 to .88 in the original version (King, King, et al., 2004). In this study, internal consistency was .82 for the Change desired in a home, and .84 in the 
community, demonstrating good reliability (Milićević \& Nedović, 2018). These values of Cronbach's alpha coefficients are comparable to those reported by the PEM-CY authors (Coster et al., 2011).

\section{Data analysis}

This study is a secondary analysis of data partially published elsewhere (Milićević \& Nedović, 2017, 2018). Normal distribution was checked using the Kolmogorov-Smirnov test (Table 2). Descriptive statistics were used to characterize the sample and the outcomes. Internal consistency was examined using Cronbach's alpha coefficients $(\alpha)$. To test the hypothesis, Spearman's rank correlation coefficients were calculated between parents' satisfaction with the children's current participation (as measured by the PEM-CY) and their perceptions of caregiving provided by services (as measured by the MPOC-20). Correlation coefficients ranging from .10 to .30 were considered low, those ranging from .31 to .50 were considered moderate, and those over .50 were considered high (Cohen, 1988). The level of significance was set at .05 .

\section{Results}

Descriptive statistics of the PEM-CY and MPOC-20 scores are briefly presented in Table 2. Overall, 64\% of parents of children with cerebral palsy have confirmed that they would like to see their child's home participation change, whereas $73 \%$ of them have expressed the desire for a change in the community participation. The highest average MPOC-20 score was noted on the Co-ordination and comprehensive care scale $(M=5.11, S D=1.34)$, while the lowest score was found on the Providing general information scale $(M=$ 4.20, $S D=1.72$ ).

Two out of 10 tested correlations have reached the level of statistical significance, both in home environment (Table 3). There were small, negative correlations between the percentages of home activities in which parents desired change and the MPOC-20's Providing general information score $\left(r_{s}=-.20, p<\right.$ $.05)$, and Providing specific information score $\left(r_{s}=-.19, p<.05\right)$. Results indicate that higher levels of perceived family-centeredness in domains of general and specific information provision are associated with higher parental satisfaction with their child's home participation. 


\section{Table 2}

Descriptive statistics of the PEM-CY and MPOC-20 scores

\begin{tabular}{|c|c|c|c|c|c|c|}
\hline \multirow{2}{*}{ Questionnaire } & \multirow{2}{*}{ Variable } & \multirow{2}{*}{$M(S D)$} & \multicolumn{2}{|c|}{$95 \%$ CI } & \multirow{2}{*}{$M d n(I Q R)$} & \multirow{2}{*}{$K S$} \\
\hline & & & $L L$ & $U L$ & & \\
\hline \multirow[b]{2}{*}{ PEM-CY } & $\begin{array}{l}\text { Change desired in } \\
\text { home participation }\end{array}$ & $63.91(24.35)$ & 61.97 & 72.02 & $70.00(40.00)$ & $.14^{* *}$ \\
\hline & $\begin{array}{l}\text { Change desired } \\
\text { in community } \\
\text { participation }\end{array}$ & $72.55(23.12)$ & 68.18 & 76.92 & $70.00(30.00)$ & $.13^{* *}$ \\
\hline \multirow{5}{*}{ MPOC- $20^{\mathrm{b}}$} & $\begin{array}{l}\text { Enabling and } \\
\text { partnership }\end{array}$ & $4.97(1.51)$ & 4.68 & 5.26 & $5.00(2.25)$ & $.11^{* *}$ \\
\hline & $\begin{array}{l}\text { Providing general } \\
\text { information }\end{array}$ & $4.20(1.72)$ & 3.86 & 4.54 & $4.20(2.40)$ & .08 \\
\hline & $\begin{array}{l}\text { Providing specific } \\
\text { information }\end{array}$ & $4.88(1.55)$ & 4.58 & 5.18 & $5.33(2.33)$ & $.13^{* *}$ \\
\hline & $\begin{array}{l}\text { Co-ordination and } \\
\text { comprehensive care }\end{array}$ & $5.11(1.34)$ & 4.86 & 5.37 & $5.50(1.75)$ & $.14^{* *}$ \\
\hline & $\begin{array}{l}\text { Respectful and } \\
\text { supportive care }\end{array}$ & $5.05(1.32)$ & 4.79 & 5.30 & $5.40(1.95)$ & $.12^{* *}$ \\
\hline
\end{tabular}

Note. PEM-CY - The Participation and Environment Measure for Children and Youth; MPOC-20 - The Measure of Processes of Care; $C I$ - confidence interval; $L L$ - lower limit; $U L$ - upper limit; $K S$ - Kolmogorov-Smirnov statistic.

${ }^{a}$ Higher scores indicate greater number of activities that parents desire change in their child's participation (possible range $0-100 \%$ ).

${ }^{\mathrm{b}}$ Higher scores indicate that parents perceive the service delivery as being family-centred to a greater extent (theoretical range 1-7).

${ }^{* *} p<.01$.

\section{Table 3}

Family-centeredness of service delivery and overall satisfaction with child's participation

\begin{tabular}{lcc}
\hline \multirow{2}{*}{ Service delivery (MPOC-20) } & \multicolumn{2}{c}{ Participation change desired (PEM-CY) } \\
\cline { 2 - 3 } & Home & Community \\
\hline Enabling and partnership & -.18 & -.18 \\
Providing general information & $-.20^{*}$ & -.13 \\
Providing specific information & $-.19^{*}$ & -.08 \\
Coordination and comprehensive care & -.09 & -.16 \\
Respectful and supportive care & -.06 & -.12 \\
\hline
\end{tabular}

Note. PEM-CY - The Participation and Environment Measure for Children and Youth; MPOC-20 - The Measure of Processes of Care.

$* p<.05$, two-tailed. 


\section{Discussion}

To our knowledge, this is the first attempt to comprehensively explore the association between family-centeredness of service delivery and participation of children with cerebral palsy concerning a specific setting. It was hypothesized that family-centeredness of service delivery would be significantly associated with the parental satisfaction with home and community participation.

Based on the presented results, parents of participants with cerebral palsy express a desire for a change in less home-based activities when they have more access to general information. At the same time, they are more satisfied with home participation when they have more specific information concerning their child with cerebral palsy. On the other hand, the desire for a change in home participation does not vary significantly with the extent to which parents experience service support as being family-centred in other MPOC-20 domains (Enabling and partnership, Coordination and comprehensive care, Respectful and supportive care). As an outcome, the fulfilment of parents' needs could have a positive effect on the subjective dimension of home participation. The aforementioned refers to parents' lack of information that could be useful in achieving broader social support or needed to understand their child's disability better. Provision of information related to the assessments results, current therapy and child's progress, as well as counselling and guidance to other sources of useful information or other organizations and associations could have a comparable effect.

Our results extend the findings of previous studies. One study showed that both social and professional support were reflected in home-based activities. As seen from the parents' perspective, this has been achieved through cooperation with the staff whose primary scope of work is early intervention (Khetani et al., 2013). Furthermore, their overall satisfaction with the child's current participation varies across different settings when related to diversity and frequency of participation, and the level of involvement of their child as well (Milićević \& Nedović, 2018). Consequently, some authors have emphasized collaborative goal setting, effective communication with families and interprofessional teamwork as components essential for resolving conceptual and practical issues of implementation of family-centred service for children with cerebral palsy and their families (King \& Chiarello, 2014).

Our finding could be interpreted as a reflection of the distribution of achievement, i.e. all MPOC-20 scores (Table 2). It is necessary to have a closer look at the finding that both Providing general information and Providing specific information domains had the lowest scores. Only these two domains were associated with the subjective dimension of home participation with confirmed statistical significance (Table 3). This may indicate which principal efforts should be taken to shape a context that improves home participation. In that case, giving clear and the most reliable information on the condition and 
prognosis could be the first step, followed by offering all necessary, written and family-friendly information that can be taken home and used subsequently. Moreover, the entire family should have opportunities to receive information, with appropriate recommendations for further medical, rehabilitation and educational services, and counselling services (King \& Chiarello, 2014; King, Teplicky, et al., 2004). These are the key steps in minimizing the impact of stress and pressure during the diagnostic process (King \& Chiarello, 2014).

When it comes to family-centeredness of service delivery and community participation, all five correlations are low and negative, without statistical significance. Therefore, it cannot be argued that changes in the extent to which parents perceived the health and rehabilitation services as being familycentred are associated with the number of community activities in which they expressed their desire for change. One of the possible explanations of this outcome could be the dominant orientation of services and professional support in Serbia to individual, functional achievements and consequent lack of effect in the social context, as reported earlier (Milićević \& Nedović, 2017). Focusing interventions on individual functional limitations, without considering the problems caused by disabling environments, barriers and cultures, is counted among the main causes of social exclusion (Barnes, 2012). Some authors point out that this tendency is, in fact, the basis for limiting the participation of persons with disabilities in various activities and life situations (Cvijetić et al., 2014). If a disability is defined as a product of the social context and the environment (Pešić, 2006), then the question is why the effects of support were not visible in the characteristics of participation of our participants. According to contemporary theoretical considerations of disability, the focus should be the following two issues: the quality of the person's functioning in a particular context, and the improvement of the person's functioning within that context, either by improving the ability of that person or through modifying his/her physical and social environment (Cvijetić et al., 2014; Wehmeyer, 2003).

Another possible explanation is related to insufficient or overlooked orientation of services and expert support to the level of the primary social system (such as the family) and the level of the immediate, wider social environment (such as local community). Among other things, families need to be informed about what the principle of family-centeredness implies and what they should expect when it comes to this type of cooperation. Here, organizations or departments that provide services have an influential position (Law et al., 2003). The same authors have highlighted that parental perceptions of family-centred service, in turn, move in a positive direction if there are fewer locations where services are delivered. This trend is also present in the case of fewer health and development problems, as well. This may indicate that services should be offered to families in an accessible way. Specifically, location or place of service delivery is an important factor, in addition to the recognition and 
respect of the family's ability to understand and accept given information and advice (Rosenbaum et al., 1998). One of the latest proposed future directions in the field of disability studies is the challenge of changing service structures in a way that provides delivery of effective 'real-world' interventions in the natural environment (Imms, 2020).

Several limitations of this study should be mentioned. First, data did not meet the strict assumptions of the parametric techniques, and statistical analysis was limited. Concerning the sample, recruitment was completed by convenience sampling. Next, the results should not be easily generalized since no population-based register is available in the Republic of Serbia, and it is not known whether this sample was representative or not. Additionally, the desire for change was taken in analysing only as a dichotomous variable (change wanted or not), without considering additional data on the type of change (frequency, involvement, variety of activities). Similarly, none of the child, family or respondent factors that may have influenced participation or familycenteredness perception was taken into account. Future studies are required to address participation more thoroughly as one of the benefits of family-centred service for children with disabilities, including cerebral palsy.

The findings contribute to the overall lack of empirical data on this topic. However, a more comprehensive understanding of the potential impact that family-centeredness of service delivery has on home and community participation is still needed. Future studies could develop specific and more detailed recommendations on how methods and strategies can be used to promote the principles of family-centred work to enhance the participation of children with cerebral palsy.

\section{Conclusion}

When it comes to the relationship between family-centeredness of service delivery and participation of children with cerebral palsy, lower extent to which parents perceived health and rehabilitation services they had been receiving as being family-centred is associated with more home-based activities in which parents have desired change. It can be concluded that those parents who perceived certain aspects of health and rehabilitation services as being family-centred to a greater extent had higher overall satisfaction with their child's current home and community participation. The parental perception of experience and professional support is reflected in their perception of the child's participation in home-based activities only. More specifically, this refers only to general information and child-related information. Contrary to the research hypothesis, our results failed to confirm the association with the community participation variable. To conclude, due to the lack of significant correlations between family-centeredness of service delivery and parental satisfaction with 
their child's participation, mostly in community, the hypothesis is rejected. This finding implies that parents need to be actively involved in teamwork, familiar with all the information they need to make decisions about future directions in special education and rehabilitation interventions.

Although different from the hypothesized, the finding of this study provides a critical overview and points to a possible insufficient representation of the concept of participation and family-centred work principles in service planning and the evaluation of outcomes of the applied programs. As known, one of the ways to enhance the likelihood that caregiving practices will meet child and family needs more fully and result in the best outcomes possible is to implement family-centred care in health care and rehabilitation organizations.

According to the results obtained, it can be underlined that parents' perceptions of their own and family's experience with service and professional support are reflected in their perceptions of the child's participation in homebased activities. The findings have implications for the role of parents. It is necessary for parents to be active members of the team and to be familiar with all the necessary general information.

\section{References}

Allen, R. I., \& Petr, C. G. (1996). Toward developing standards and measurements for family-centered practice in family support programs. In G. H. S. Singer, L. E. Powers, \& A. L. Olson (Eds.), Redefining family support: Innovations in publicprivate partnerships (pp. 57-86). Paul H. Brookes.

Arakelyan, S., Maciver, D., Rush, R., O'Hare, A., \& Forsyth, K. (2019). Family factors associated with participation of children with disabilities: A systematic review. Developmental Medicine \& Child Neurology, 61(5), 514-522. https://doi.org/10.1111/dmen.14133

Barnes, C. (2012). Re-thinking disability, work and welfare. Sociology Compass, 6(6), 472-484. https://doi.org/10.1111/j.1751-9020.2012.00464.x

Cohen, J. (1988). Statistical power analysis for the behavioral sciences. Lawrence Earlbaum Associates.

Coster, W., Bedell, G., Law, M., Khetani, M. A., Teplicky, R., Liljenquist, K., Gleason, K, \& Kao, Y.-C. (2011). Psychometric evaluation of the Participation and Environment Measure for Children and Youth. Developmental Medicine \& Child Neurology, 53(11), 1030-1037. https://doi.org/10.1111/j.1469-8749.2011.04094.x

Coster, W., Law, M., \& Bedell, G. (2010). Participation and Environment Measure for Children and Youth. Boston University.

Coster, W., Law, M., Bedell, G., Khetani, M., Cousins, M., \& Teplicky, R. (2012). Development of the participation and environment measure for children and youth: Conceptual basis. Disability and Rehabilitation, 34(3), 238-246. https://doi.org/10.3109/09638288.2011.603017

Cvijetić, M., Slavnić, S., \& Stanimirović, D. (2014). Klasifikacija „Nastajanje situacije hendikepa"kao okvir za procenu i unapređenje socijalne participacije [Classification "Disability Creation Process" as a framework for the assessment and improvement of social participation]. Beogradska defektološka škola, 20(3), 701-713. 
Darrah, J., Magil-Evans, J., \& Adkins, R. (2002). How well are we doing? Families of adolescents or young adults with cerebral palsy share their perceptions of service delivery. Disability and Rehabilitation, 24(10), 542-549.

https://doi.org/10.1080/09638280210121359

Davis, E., Mackinnon, A., \& Waters, E. (2012). Parent proxy-reported quality of life for children with cerebral palsy: Is it related to parental psychosocial distress? Child: Care, Health and Development, 38(4), 553-560. https://doi.org/10.1111/j.1365-2214.2011.01267.x

Engel-Yeger, B., Jarus, T., Anaby, D., \& Law, M. (2009). Differences in patterns of participation between youths with cerebral palsy and typically developing peers. American Journal of Occupational Therapy, 63(1), 96-104. https://doi.org/10.5014/ajot.63.1.96

Imms, C.(2008). Childrenwithcerebralpalsy participate:Areview of theliterature.Disability and Rehabilitation, 30(24), 1867-1884. https://doi.org/10.1080/09638280701673542

Imms, C. (2020). Participation in diverse life situations for people with disability: A vision for the future. Developmental Medicine \& Child Neurology, 62(1), 5-5. https://doi.org/10.1111/dmcn.14399

Imms, C., Reilly, S., Carlin, J., \& Dodd, K. (2008). Diversity of participation in children with cerebral palsy. Developmental Medicine \& Child Neurology, 50(5), 363-369. https://doi.org/10.1111/j.1469-8749.2008.02051.x

Khetani, M. A., Cohn, E. S., Orsmond, G. I., Law, M. C., \& Coster, W. J. (2013). Parent perspectives of participation in home and community activities when receiving Part C early intervention services. Topics in Early Childhood Special Education, 32(4), 234-245. https://doi.org/10.1177/0271121411418004

King, G., \& Chiarello, L. (2014). Family-centered care for children with cerebral palsy: Conceptual and practical considerations to advance care and practice. Journal of Child Neurology, 29(8), 1046-1054. https://doi.org/10.1177/0883073814533009

King, S., King, G., \& Rosenbaum, P. (2004). Evaluating health service delivery to children with chronic conditions and their families: Development of a refined measure of processes of care (MPOC-20). Children's Health Care, 33(1), 35-57. https://doi.org/10.1207/s15326888chc3301_3

King, G., King, S., Rosenbaum, P., \& Goffin, R. (1999). Family-centered caregiving and well-being of parents of children with disabilities: Linking process with outcome. Journal of Pediatric Psychology, 24(1), 41-53. https://doi.org/10.1093/jpepsy/24.1.41

King, S., Rosenbaum, P., \& King, G. (1995). The Measure of Processes of Care: A means to assess family-centred behaviours of health care providers. McMaster University, Neurodevelopmental Clinical Research Unit.

King, S., Rosenbaum, P., \& King, G. (1996). Parents' perceptions of caregiving: Development and validation of a measure of processes. Developmental Medicine \& Child Neurology, 38(9), 757-772. https://doi.org/10.1111/j.1469-8749.1996.tb15110.x

King, S., Teplicky, R., King, G., \& Rosenbaum, P. (2004). Family-centered service for children with cerebral palsy and their families: A review of the literature. Seminars in Pediatric Neurology, 11(1), 78-86. https://doi.org/10.1016/j.spen.2004.01.009

Law, M. (2002). Enhancing participation. Physical \& Occupational Therapy In Pediatrics, 22(1), 1-3. https://doi.org/10.1080/J006v22n01_01

Law, M., Hanna, S., King, G., Hurley, P., King, S., Kertoy, M., \& Rosenbaum, P. (2003). Factors affecting family-centred service delivery for children with disabilities. Child: Care, Health and Development, 29(5), 357-366. https://doi.org/10.1046/j.1365-2214.2003.00351.x

Majnemer, A., Shevell, M., Law, M., Birnbaum, R., Chilingaryan, G., Rosenbaum, P., \& Poulin, C. (2008). Participation and enjoyment of leisure activities in school-aged 
children with cerebral palsy. Developmental Medicine \& Child Neurology, 50(10), 751-758. https://doi.org/10.1111/j.1469-8749.2008.03068.x

Milićević, M. (2019). Home participation of children with and without cerebral palsy in Serbia: An exploratory study. Disability and Rehabilitation, https://doi.org/10.1080 /09638288.2019.1610506

Milićević, M., \& Nedović, G. (2017). Ispitivanje primene pristupa usmerenog na porodice dece s cerebralnom paralizom [Evaluating implementation of family-centered approach in families with children with cerebral palsy]. Godišnjak Fakulteta političkih nauka, 11(18), 165-194.

Milićević, M., Nedović, G., \& Bogdanović Šutković, V. (2017). Community participation and family quality of life - comparative study of children with cerebral palsy and children with typical development. In M. Filipović \& B. Brojčin (Eds.), Early Childhood Intervention: For Meeting Sustainable Development Goals of the New Millennium: proceedings, Eurlyaid Conference 2017, Belgrade, Serbia October, 6-8th 2017 (pp. 251-259). University of Belgrade, Faculty of Special Education and Rehabilitation.

Milićević, M., \& Nedović, G. (2018). Comparative study of home and community participation among children with and without cerebral palsy. Research in Developmental Disabilities, 80, 74-83. https://doi.org/10.1016/j.ridd.2018.06.010

Pešić, V. (2006). Evropska unija i osobe sa invaliditetom [The European Union and people with disabilities]. Friedrich Ebert Stiftung, Narodna kancelarija predsednika Republike.

Rosenbaum, P. (2003). Cerebral palsy: what parents and doctors want to know. British Medical Journal (BMJ Clinical Research Ed.), 326(7396), 970-974. https://doi. org/10.1136/bmj.326.7396.970

Rosenbaum, P. (2009). Cerebral palsy in the 21st century: what's new? In C. Morris \& D. Condie (Eds.), Recent Developments in Healthcare for Cerebral Palsy: Implications and Opportunities for Orthotics (Report of a meeting held at Wolfson College, Oxford, 8-11 September 2008) (pp. 25-39). International Society for Prosthetics and Orthotics.

Rosenbaum, P., King, S., Law, M., King, G., \& Evans, J. (1998). Family-centred service: A conceptual framework and research review. Physical \& Occupational Therapy In Pediatrics, 18(1), 1-20. https://doi.org/10.1080/J006v18n01_01

Rosenbaum, P., Paneth, N., Leviton, A., Goldstein, M., Bax, M., Damiano, D., Dan, B, \& Jacobsson, B. (2007). A report: The definition and classification of cerebral palsy April 2006. Developmental Medicine \& Child Neurology, 49(Suppl.109), 8-14.

Shevell, M., Oskoui, M., Wood, E., Kirton, A., Van Rensburg, E., Buckley, D., Ng, P., \& Majnemer, A. (2019). Family-centred health care for children with cerebral palsy. Developmental Medicine \& Child Neurology, 61(1), 62-68. https://doi.org/10.1111/ dmen.14053

Shikako-Thomas, K., Majnemer, A., Law, M., \& Lach, L. (2008). Determinants of participation in leisure activities in children and youth with cerebral palsy: Systematic review. Physical \& Occupational Therapy in Pediatrics, 28(2), 155-169. https://doi.org/10.1080/01942630802031834

Taboroši, M. (2015). Roditeljska percepcija kvaliteta usluga za decu sa smetnjama u razvoju u Srbiji [Parental perception of the quality of services for children with disabilities in Serbia] [Master thesis, Univerzitet u Beogradu]. Univerzitet $\mathrm{u}$ Beogradu, Fakultet za specijalnu edukaciju i rehabilitaciju. 
Wehmeyer, M. L. (2003). Defining mental retardation and ensuring access to the general curriculum. Education and Training in Developmental Disabilities, 38(3), 271-282.

World Health Organization. (2001). International classification of functioning disability and health (ICF). World Health Organization.

World Health Organization. (2004). International statistical classification of diseases and related health problems (ICD-10). World Health Organization.

\title{
Povezanost pristupa usmerenog na porodicu i zadovoljstva roditelja participacijom dece sa cerebralnom paralizom u kućnom okruženju i u okruženju zajednice
}

\author{
Milena D. Milićevića , Goran M. Nedovićb \\ ${ }^{a}$ Institut za kriminološka i sociološka istraživanja, Beograd, Srbija \\ ${ }^{b}$ Univerzitet u Beogradu - Fakultet za specijalnu edukaciju i rehabilitaciju, Beograd, Srbija
}

Cilj ove deskriptivne i eksplorativne studije je bio da se ispita odnos između usmerenosti na porodicu u pružanju usluga i participacije dece s cerebralnom paralizom u kućnom okruženju i okruženju zajednice. Postavljena je hipoteza prema kojoj postoji statistički značajna povezanost između usmerenosti na porodicu u pružanju usluga i roditeljskog zadovoljstva participacijom u kućnom okruženju i okruženju zajednice u grupi dece s cerebralnom paralizom školskog uzrasta. Prigodan uzorak je obuhvatio 110 dece s cerebralnom paralizom starosti $7-18$ godina (55\% muškog pola; prosečnog uzrasta 12,7 godina, $S D=3.41)$. Za procenu obima u kojem roditelji dece sa cerebralnom paralizom doživljavaju dobijene zdravstvene i rehabilitacione usluge kao usmerene na porodicu korišćena je skala Merenje procesa nege (Measure of Processes of Care - MPOC-20). Sveukupno roditeljsko zadovoljstvo participacijom deteta u kućnom okruženju i okruženju zajednice procenjeno je primenom Testa za procenu participacije $i$ okruženja - Deca $i$ mladi (Participation and Environment Measure for Children and Youth - PEM-CY). Analize su izvršene pomoću koeficijenata Spirmanove korelacije ranga. Samo dve od 10 testiranih korelacija dostigle su nivo statističke značajnosti, obe u kućnom okruženju. Roditelji koji su izrazili veće sveukupno zadovoljstvo trenutnom participacijom svog deteta u kućnom okruženju i okruženju zajednice doživljavali su određene aspekte zdravstvenih i rehabilitacionih usluga kao usmerene na porodicu u većem obimu (opšte i posebne informacije). Pružanjem opštih informacija i informacija o detetu ispunjavaju se roditeljske potrebe što može imati pozitivan uticaj na njihovo zadovoljstvo participacijom dece u kući. Nalazi ukazuju na nedovoljnu zastupljenost koncepta participacije i principa rada usmerenog na porodicu u planiranju usluga i evaluaciji rezultata primenjenih programa.

Ključne reči: participacija, deca sa cerebralnom paralizom, usluga usmerena na porodicu, podrška porodici 